\title{
PERKEMBANGAN, PRODUKSI, DAN PERAN KULTUR MIKROALGA LAUT DALAM INDUSTRI
}

\author{
Oleh \\ Diah Radini Noerdjito ${ }^{1)}$
}

\begin{abstract}
DEVELOPMENT, PRODUCTION, AND THE ROLE OF MARINE MICROALGA IN INDUSTRY. Microalgae cultures recently have been used for various purposes. Culture development of microalgae started from the late 1800 s and still continue until now. Specific media composition, lighting, aeration, culture system were applied to many different species microalgae for specific purposes such as pharmaceutical, healthcare, cosmetics, environmental management, energy production, and aquaculture.
\end{abstract}

\section{PENDAHULUAN}

Mikroalga adalah organisme eukariot yang berukuran mikro. Organisme ini mempunyai struktur sangat sederhana, dan dapat terdiri dari satu atau banyak sel. Mikroalga mempunyai kemampuan berfotosintesis, yaitu dengan bantuan sinar matahari dapat menangkap dan mengubah karbondioksida menjadi cadangan energi kimia di tubuhnya. Mikroalga dapat ditemukan di berbagai tempat dimana terdapat air dan sinar matahari (Guschina \& Harwood, 2006).

Mikroalga merupakan dasar dari rantai makanan di laut (Andersen, 1992). Oleh karena itu, mikroalga digunakan dalam usaha komersial budidaya biota laut sebagai sumber pakan antara lain pada tahap pertumbuhan moluska bivalvia, tahap larva beberapa spesies udang-udangan, dan tahap larva awal pada beberapa spesies ikan (Coutteau, 1996). Selain itu, mikroalga juga digunakan dalam produksi massal zooplankton (rotifer, copepod, brine shrimp/artemia) seperti yang dijelaskan oleh Reitan et al. (1997). Zooplankton tersebut kemudian digunakan sebagai pakan larva dan tahap awal juvenile ikan dan udang-udangan.

Sintesis lemak atau lipida adalah salah satu cara bagi mikroalga untuk menyimpan karbon dan energi. Dalam kondisi yang tertekan secara fisiologis, misalnya karena faktor nutrien atau proses foto-oksidasi, mikroalga dapat menyimpan lipida hingga 70\% dari berat keringnya (Schenk et al. 2008). Lipida pada mikroalga mengandung berbagai jenis asam lemak yang dapat dimanfaatkan lebih lanjut, misalnya untuk bahan baku obat-obatan (Mimoumi et al,

\footnotetext{
1) Pusat Penelitian Oseanografi, Lembaga Ilmu Pengetahuan Indonesia
} 
2011; Skjanes et al., 2012), budidaya biota (Roy \& Pal, 2015), dan bioenergi (Chisty, 2007). Sebagai contoh, asam lemak rantai panjang (long chain polyunsaturated fatty acids (PUFA) adalah asam lemak yang mengandung lebih dari 18 atom karbon dan mempunyai paling tidak satu ikatan rangkap di dalam struktur molekulnya. PUFA dalam bentuk arachidonic acid (AA), linolenic acid, eicosapentaenoic acid (EPA), docosapentaenoic acid (DPA), dan docosahexaenoic acid (DHA) merupakan bahan penting untuk nutrisi manusia dan biota budidaya (Stengel et. al., 2011). Jenis asam lemak yang dihasilkan oleh mikroalga berbeda-beda, tergantung oleh spesiesnya (Renaud et. al., 1999). Kandungan lipid juga dipengaruhi oleh tekanan akibat kurangnya kadar nitrogen (Adams et al., 2013).

Jenis-jenis mikroalga yang sangat banyak, serta potensinya yang sangat beragam, membuat mikroalga sangat menarik untuk diteliti lebih lanjut. Mikroalga memilili ukuran yang sangat kecil, sehingga diperlukan jumlah mikroalga yang sangat banyak untuk dapat dipergunakan lebih lanjut. Pemanfaatan mikroalga tidak dapat dilakukan secara optimal tanpa kultur mikroalga. Perbanyakan mikroalga membutuhkan metode dan teknik kultur yang sesuai untuk setiap jenis mikroalga yang berbeda, dan terus berkembang dari waktu ke waktu.

\section{SEJARAH DAN PERKEMBANGAN KULTUR MIKROALGA}

Menurut Preisig \& Andersen
(2005), pengembangan kultur dan medium tumbuh mikroalga telah berlangsung dari akhir tahun 1800an. Publikasi mengenai kultur mikroalga pertama kali diterbitkan pada tahun 1850 oleh Ferdinand Cohn yang telah berhasil menumbuhkan kultur Haematococcus di laboratorium dengan menggunakan metode yang disebutnya prosedur cultivation. Namun Cohn tidak mengisolasi Haematococcus dari organisme lain, tidak menggunakan medium kultur, dan tidak membuat kultur yang dipelihara terus menerus. Orang yang pertama kali menumbuhkan mikroalga dalam larutan garam anorganik adalah Famintzin dari Rusia pada tahun 1971. Ia menumbuhkan beberapa jenis alga hijau antara lain Chlorococcum infusionum dan Protococcus viridis.

Orang yang pertama kali dilaporkan telah berhasil mengkultur mikroalga secara axenic atau bebas bakteri adalah M.W. Beijerinck dari Belanda pada tahun 1890 (Preisig \& Andersen, 2005). Ia mengadopsi metode kultur bakteri yang dikembangkan oleh Robert Koch pada tahun 1880. Beijerinck berhasil mengkultur Chlorella (1890) dan Scenedesmus (1892) dengan mencampur air sampel yang mengandung mikroalga, medium, dan gelatin. Beijerinck juga orang pertama yang berhasil mengisolasi mikroalga hijau yang bersimbiosis dengan hydra dan lichenes. Ia kemudian juga dapat mengembangkan kultur murni cyanobacteria (1901), dan diatom (1904).

Tokoh lain yang berperan besar dalam pengembangan kultur mikroalga adalah P. Miquel, seorang ahli mikrobi- 
ologi dari Perancis. Ia berhasil mengkultur diatom air tawar dan air laut secara axenic. Ia juga memperkenalkan beberapa metode baru, antara lain menggunakan mikropipet untuk mengisolasi sel mikroalga, dan menambahkan lumut, tangkai gandum, potongan rumput sebagai sumber bahan organik. Miquel juga mengembangkan metode isolasi menggunakan prinsip pengenceran (dilution isolation method). Metode untuk mendapatkan kultur murni diatom juga dikembangkan oleh L. Macchiati (1892) dari Italia (Supriya \& Ramachandra, 2011).

Penggunaan gelatin dalam metode kultur mikroalga kemudian digantikan dengan penggunaan agar oleh G. Kleb (1896). Hal ini disebabkan karena hasil kultur menggunakan gelatin tidak memberikan hasil yang memuaskan. Bakteri ternyata dapat mencerna gelatin sehingga mengubah gelatin yang semula berwujud padat menjadi cair. H.M. Ward (1899) kemudian merekomendasikan untuk menambahkan asam asetat ke dalam agar untuk mencegah kontaminasi pada agar (Supriya \& Ramachandra, 2011).

Pada abad ke-20, penelitian mengenai kultur mikroalga semakin berkembang (Supriya \& Ramachandra, 2011). H. Zumstein (1900) mengisolasi sel tunggal mikroalga menggunakan pipet kapiler, dan ia mencegah kontaminasi bakteri dengan cara membuat medium kultur seasam mungkin tanpa membunuh sel mikroalga. Setelah sekitar 30 tahun penelitian dan berhasil mengkultur secara murni sekitar 300 spesies mikroalga, $\mathrm{R}$.
Chodat (1928) menemukan bahwa pada mikroalga yang dikultur secara berbeda dengan kondisi di alam secara morfologi tumbuh secara abnormal. O. Richter dari Austria yang bekerjasama dengan Miquel pada tahun 1911 menyampaikan publikasi yang mendetail mengenai kandungan nutrisi pada mikroalga. Henriette Chick dari Inggris mengemukakan bahwa Chlorella pyrenoidosa yang dikultur secara axenic lebih menyukai amonia daripada nitrat sebagai sumber nitrogen.

Pada tahun 1911, E.J. Allen, Direktur Marine Biological Association of United Kingdom dan rekannya Nelson memberikan kontribusi besar terhadap perkembangan kultur mikroalga melalui kultivasi mikroalga untuk memelihara organisme laut. Mereka mengisolasi dan mengkultur Chaetoceros, Skeletone$m a$, dan Thallasiossira untuk memberi makan larva organisme laut, dan fitoplanton tersebut hingga saat ini menjadi sumber pakan utama di panti benih budidaya (aquaculture hatcheries). Mereka juga membuat air laut buatan (artificial seawater) berdasarkan konsentrasi air laut yang dijabarkan oleh J.H. Van't Hoff pada tahun 1905 (Preisig \& Andersen, 2005).

Allen dan Nelson mengkultur mikroalga dalam skala besar (mass culture), berbeda dengan pendahulunya yang yang mengkultur dalam test tube atau flask culture, sehingga mereka mengalami masalah yang berbeda pula. Mereka mendapati bahwa cahaya merupakan faktor pembatas dalam kultur skala besar. Selain itu, dibutuhkan perlakuan khusus untuk men- 
sterilisasi air laut yang akan digunakan. Mereka memurnikan air laut dalam skala besar dengan mendidihkan air laut dan menyaringnya dengan animal-charcoal filter, dan menambahkan hidrogen peroksida (Preisig \& Andersen, 2005).

Pada tahun 1912, E.G. Pringsheim mempublikasikan beberapa paper mengenai metode kultur mikroalga. Pada tahun 1921, Pringsheim menemukan bahwa asetat merupakan medium kultur yang cocok bagi mikroalga heterotrofik. Ia kemudian membangun koleksi kultur mikroalga di Halle an der Saale Jerman (1921), German University di Praha (1928), Culture Center of Algae and Protozoa (CCAP) di Cambridge Inggris, dan Sammlung von Algenkulturen (SAG) di Gottingen Jerman (1953). Secara total, ia telah membuat sekitar 2000 kultur mikroalga dari sekitar 400 spesies (Preisig $\&$ Andersen, 2005).

Seorang ahli fisiologi Jerman bernama Warburg pada tahun 1919 menemukan bahwa mikroalga hijau (misalnya Chlorella) merupakan bahan eksperimen yang ideal untuk penelitian fotosintesis dari sisi biokimia dan fisiologi (Preisig \& Andersen, 2005). Ia menambahkan gelembung udara berisi $\mathrm{CO}_{2}$ secara berkelanjutan ke dalam kultur mikroalga. Ia juga menambahkan pencahayaan buatan dalam eksperimen, untuk mempelajari proses fotosintesis.

Dalam bidang sistematik dan evolusi mikroalga, tokoh yang berperan penting adalah Geitler (Austria), Kornmann (Jerman), dan Von Stosch (Jerman) pada tahun 1920-1930an. Mereka meng- gunakan kultur mikroalga untuk mempelajari sistematika dan evolusi mikroalga (Preisig \& Andersen, 2005).

Ahli lain, yaitu Schreiber, pada tahun 1925 mengembangkan medium kultur dengan penambahan fosfat dan nitrat (Preisig \& Andersen, 2005). Medium ini dibuat berdasarkan kebutuhan minimum fosfat dan nitrat yang dibutuhkan oleh diatom untuk tumbuh. Chu (1933) mengembangkan media (Chu medium number 10) yang dapat menumbuhkan mikroalga secara natural. Ahli lain yang berperan penting dalam pengembangan medium tumbuh mikroalga adalah Guillard (1962) yang masih umum digunakan hingga saat ini.

\section{KULTUR MIKROALGA SKALA BESAR}

Kultur mikroalga dengan kepadatan yang tinggi pertama kali berhasil dilakukan oleh Warburg (1919) di Berlin Jerman (Preisig \& Andersen, 2005). Ketchum \& Redfield (1938) berhasil menjaga keberlangsungan kultur diatom laut dengan menggunakan metode pemanenan jangka waktu tertentu (periodic harvesting) pada saat kultur tertutup (batch) mencapai fase tertentu pada kurva tumbuhnya. Kultur yang tersisa di dalam tempat kultur kemudian ditumbuhkan lagi hingga mencapai kepadatan yang diinginkan. Sistem kultur ini di kemudian hari berkembang menjadi semi countinuous batch culture method (Preisig \& Andersen, 2005).

Kultur mikroalga skala besar yang paling banyak dikembangkan ada- 
lah kultur Chlorella sp. Mikroalga ini banyak digunakan sebagai bahan tambahan makanan protein sel tunggal. Di Jepang, mulai tahun 1953 dikembangkan sistem kultur synchronous culture technique pada Chlorella sp. Sistem ini mengkoordinasikan siklus hidup setiap individu pada populasi mikroalga untuk mendapatkan pertumbuhan kultur yang optimal. Penelitian ini kemudian dilanjutkan dengan menggunakan berbagai spesies yang lain (Preisig \& Andersen, 2005).

\section{PRODUKSI KULTUR MIKROALGA}

Kultur skala besar mikroalga dilakukan untuk berbagai keperluan, di Amerika, misalnya untuk memproduksi protein sel tunggal Chlorella sp seperti yang dilakukan di Texas dan California AS. Hal penting dalam kultur skala besar adalah panen secara periodik untuk mempertahankan kepadatan optimum agar mikroalga tetap dapat tumbuh dengan baik.

Ada beberapa hal penting yang harus diperhatikan dalam memproduksi mikroalga. Namun, setiap parameter yang digunakan dapat berbeda untuk setiap jenis mikroalga. Menurut Coutteau (1996),hal- hal penting dalam kultur mikroalga adalah sebagai berikut :

- Jenis dan konsentrasi nutrien dalam media

Kepadatan mikroalga dalam kultur jauh lebih tinggi daripada kepadatan mikroalga yang ditemukan di alam. Oleh karena itu, kultur mikroalga harus diperkaya dengan nutrien. Makronutrien penting dalam kultur mikroalga adalah nitrat, fosfat, dan silikat. Mikronutrien terdiri dari trace metal, thiamine (vitamin $\mathrm{B}_{1}$ ), cyanocobalamin $\left(\mathrm{B}_{12}\right)$, dan biotin. Dua jenis media yang umum digunakan dalam mengkultur mikroalga adalah Walne dan Guillard f/2.

- Cahaya

Sebagai organisme yang berfotosisntesis, cahaya berperan penting dalam kultur mikroalga. Intensitas cahaya yang diperlukan dalam kultur mikroalga tergantung kepada kedalaman dan konsentrasi sel. Cahaya dapat berasal dari cahaya matahari ataupun dari lampu fluoresens. Hal penting lain yang perlu diperhatikan adalah fotoperiodisme cahaya.

- $\mathrm{pH}$

Kisaran $\mathrm{pH}$ untuk kultur mikroalga adalah 7-9 dengan kisaran opti-

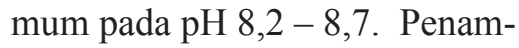
bahan karbondioksida pada proses aerasi akan mengurangi penambahan $\mathrm{pH}$ selama kultur.

- Aerasi/mixing

Aerasi penting untuk mencegah sedimentasi pada mikroalga, membuat semua sel mikroalga terekspos cahaya dan nutrien secara merata, dan meningkatkan pertukaran gas antara kultur media dan udara. 
- Salinitas

Salinitas yang sesuai untuk kultur mikroalga dapat berbeda-beda, tergantung jenis mikroalga yang dikultur.

- Suhu

Suhu yang sesuai untuk kultur mikroalga dapat berbeda-beda, tergantung jenis mikroalga yang dikultur.

Proses produksi mikroalga terdiri dari tiga tahapan penting yaitu isolasi, kultur/perbanyakan, dan pemanenan. Proses isolasi mikroalga biasanya dilakukan dengan menggunakan metode single cell isolation menggunakan pipet kapiler dari pipet Pasteur (Anderson, 2005). Satu sel mikroalga hasil isolasi kemudian ditumbuhkan dalam multi-well plate yang berisi cairan media. Kultur tersebut kemudian diletakkan di suatu tempat dengan intensitas cahaya tertentu. Setelah beberapa lama dan dapat tumbuh dengan baik, mikroalga kemudian ditumbuhkan ke dalam tabung reaksi. Tabung reaksi berisi kultur tersebut kemudian juga diletakkan di suatu tempat dengan intensitas cahaya tertentu selama beberapa lama hingga berkembang dengan baik. Kultur mikroalga yang telah tumbuh kemudian dikultur dalam erlenmeyer 40 $\mathrm{mL}$. Demikian selanjutnya sehingga diperoleh kultur sebanyak yang kita inginkan (Gambar 1).

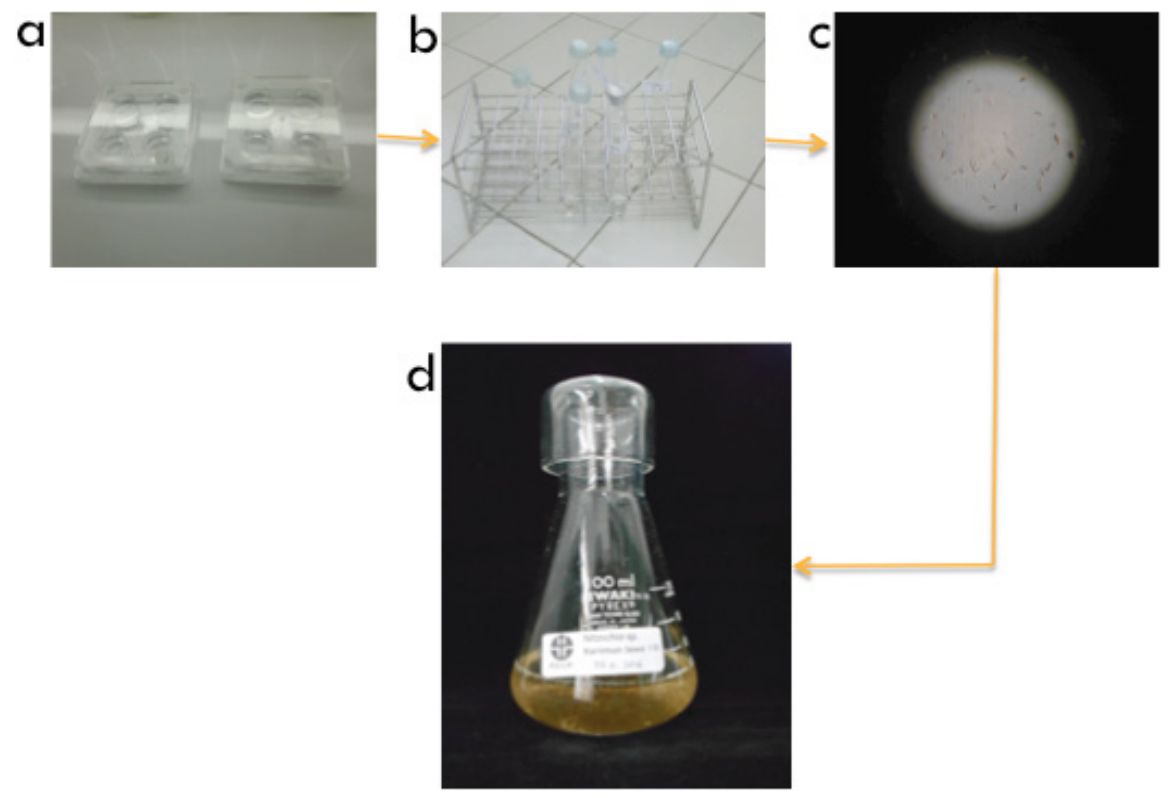

Gambar 1. Pengembangan kultur mikroalga laut : a) kultur awal dalam multi-well plate, b) kultur dalam tabung reaksi, c) kultur yang telah berkembang apabila dilihat menggunakan mikroskop cahaya, d) kultur dalam erlenmeyer $40 \mathrm{~mL}$. (Sumber foto : pribadi) 
Untuk produksi massal dalam skala yang besar, kultur dapat dilakukan dengan berbagai jenis sistem. Sistem apa yang hendak diterapkan tergantung pada jenis dan sifat mikroalga, berapa banyak mikroalga yang ingin diproduksi, kondisi lingkungan, dan sumber daya yang kita miliki. Keuntungan dan kekurangan dari masing-masing sistem dapat dilihat pada Tabel 1.

Tabel 1. Kelebihan dan kekurangan dari beberapa sistem kultur mikroalga

\begin{tabular}{|c|c|c|}
\hline Tipe Kultur & Keuntungan & Kerugian \\
\hline Indoor (dalam ruang) & Lebih terkontrol & Mahal \\
\hline Outdoor (luar ruang) & Murah & Kurang terkontrol \\
\hline Sistem tertutup & Kontaminasi rendah & Mahal \\
\hline Sistem terbuka & Murah & Kontaminasi tinggi \\
\hline $\begin{array}{l}\text { Axenic (steril, bebas dari } \\
\text { kontaminan misalnya bakteri) }\end{array}$ & $\begin{array}{l}\text { Terprediksi, kultur ber- } \\
\text { tahan lebih lama }\end{array}$ & Mahal, sulit \\
\hline Non-axenic & Lebih murah, lebih mudah & Kultur lebih cepat crash \\
\hline Kontinyu & $\begin{array}{l}\text { Efisien, konsisten mem- } \\
\text { produksi sel dengan kua- } \\
\text { litas baik, otomatisasi, laju } \\
\text { produksi tinggi. }\end{array}$ & $\begin{array}{l}\text { Sulit, umumnya dilakukan } \\
\text { pada kultur dengan ukuran/ } \\
\text { volume yang tidak terlalu } \\
\text { besar }\end{array}$ \\
\hline Semi kontinyu & $\begin{array}{l}\text { Lebih mudah dari sistem } \\
\text { kontinyu, cukup efisien }\end{array}$ & Kurang andal \\
\hline Batch & Paling mudah, andal & $\begin{array}{l}\text { Kurang efisien, kualitas pro- } \\
\text { duksi mungkin kurang kon- } \\
\text { sisten }\end{array}$ \\
\hline
\end{tabular}

\section{PENGGUNAAN KULTUR MIKROALGA}

Dewasa ini, penggunaan mikroalga dalam industri telah berkembang dengan sangat pesat. Perkembangan penelitian mengenai mikroalga juga sangat menunjang meningkatnya penggunaan mikroalga dalam skala industri. Mikroalga digunakan secara luas dalam bidang farmasi, kesehatan, kosmetika, manajeman lingkungan, produksi bioenergi, dan akuakultur
(Spolaore et al., 2006).

Dalam bidang budidaya, tidak semua spesies mikroalga dapat digunakan untuk mendukung pertumbuhan dan kesintasan dalam budidaya biota laut. Beberapa jenis mikroalga telah diseleksi berdasarkan potensinya untuk dikultur secara massal, ukuran sel, kemudahan dicerna, dan kandungan nutrisinya. Beberapa teknik juga telah dikembangkan untuk memproduksi mikroalga secara 
massal. Namun, diperlukan teknik dan perlakuan yang spesifik untuk setiap spesies mikroalga agar kultur dapat tumbuh secara baik dan optimal.

Mikroalga mempunyai kandungan nutrisi yang berbeda, tergantung pada jenisnya. Secara umum, protein adalah komponen terbesar dalam mikroalga, diikuti oleh lemak dan karbohidrat. Mikroalga mempunyai kisaran rata-rata kandungan protein sekitar $12-35 \%$ dari berat kering, lipid sebesar 7,2-23\% dari berat kering, dan karbohidrat sebesar 4,6$23 \%$ dari berat kering. Skeletonema sp. dan Chaetoceros sp. umumnya mempunya konsentrasi EPA yang tinggi, sedangkan Isocrysis sp. mempunyai konsentrasi DHA yang tinggi. Mikroalga juga mempunyai konsensentrasi ascorbic acid yang tinggi (0,11-1,62\% dari berat kering).

Di bidang kesehatan, senyawa aktif pada mikroalga digunakan antara lain untuk antimikroba, antivirus, antijamur, obat, protein theuraphetic, dan produk neuroprototektif. Mikroalga biru hijau Spirulina platensis sedang dikembangkan sebagai bahan pengobatan penyakit degeneratif seperti alzeimer. Penelitian awal pada mikroalga Nitzschia dari perairan Indonesia mempunyai potensi sebagai anti bakteri. Mikroalga lain dari perairan Indonesia juga banyak yang mempunyai potensi untuk dimanfaatkan lebih lanjut sebagai pencegah dan penanganan berbagai penyakit seperti atherosclerosis, thrombosis, arthritis, dan kanker,
Di bidang energi, mikroalga yang menghasilkan lipida/minyak dalam persentase yang cukup banyak dianggap potensial sebagai sumber biofuel. Menurut Sazdanof (2003) dan Chisty (2007), mikroalga merupakan depositor hidrokarbon. Mikroalga menjadi kandidat yang potensial untuk memproduksi lipida karena mempunyai kandungan lipida yang tinggi, pertumbuhan yang cepat, tidak membutuhkan alih fungsi lahan, tidak berkompetisi dengan kebutuhan pangan, dan tidak membutuhkan area tumbuh yang lebih luas bila dibandingkan dengan jenis tumbuhan lain (Chisti, 2007; Schenk et. al., 2008).

Mikroalga yang menghasilkan minyak dalam persentase yang cukup banyak adalah Bacillariophyceae (diatom, misalnya Chaetoceros, Nitzschia), Chlorophyceae (Chlorella, Nannochloropsis), dan Botryococcus braunii. Minyak pada mikroalga mempunyai berbagai jenis hidrokarbon rantai panjang yang bervariasi (Guschina \& Harwood, 2006).

\section{PENUTUP}

Pemanfaatan mikroalga yang sangat beragam ini menjadikan kultur mikroalga menjadi sangat penting untuk dilakukan. Kultur mikroalga, terutama spesies lokal Indonesia, menjadi sangat menarik untuk dilakukan, diteliti, dikembangkan, dan digunakan untuk kesejahteraan Indonesia. 


\section{DAFTAR PUSTAKA}

Adams, C., V. Godfrey, B. Wahlen, L. Seefeldt, and B. Bugbee. 2013. Understanding precision nitrogen stress to optimize the growth and lipid content trade off in oleaginous green microalgae. Bioresources Technology. 131:188-194

Anderson, R.A. 1992. Diversity of Eukaryotic Algae. Biodiversity and Conservation 1 (4): 267-292

Anderson, R.A. 2005. Algal Culturing Techniques. Elsevier, Burlington. 578 hal

Coutteau P. 1996. Micro-algae. Dalam Manual on the production and the use of live food on aquaculture (P. Lavens P \& P. Sorgeloos eds). Food and Agriculture Organization of the United Nations. Pp : $7-48$

Chisty Y. 2007. Biodiesel from microalgae. Biotechnology Advances 25(3): 294-306 (http:// dx.doi.org/10.1016/j.biotechadv.2007.02.001)

Guillard, L.L.R and J.H. Ryther. 1962. Studies of marine planktonic diatom I. Cyclotella nana Hustedt and Detonula confervacea Cleve. Can. J. Microbiol. 8:229-239
Guschina, I.A. and J.L. Harwood 2006. Lipids and lipid metabolism in eukaryotic algae. Prog. Lipid Res. 45:160-186.

Mimouni, V., L. Ulmann, V. Pasquet, M. Mathieu, L. Picot, G. Bougaran, J. Cadoret, A. Morant-Manceau, and B. Schoefs. 2012. The Potential of Microalgae for the Production of Bioactive Molecules of Pharmaceutical Interest. Current Pharmaceutical Biotechnology 13(15): 2733-2750

Preisig, H. R. and R.A. Andersen. 2005. Historical review of Algal Culturing Techniques. Dalam: Algal Culturing Techniques (R. A. Andersen eds.). Elsevier, Burlington $: 1-12$

Reitan, K.I., J.R. Rainuzzo, G. Oie, and Y. Olsen. 1997. A review of the nutritional effects of algae in marine fish larvae. Aquaculture. 155 (1): 207211

Renaud, S. M., L.V. Thinh, and D.L. Parry. 1999. The gross chemical composition and fatty acid composition of 18 species of tropical Australian microalgae for possible use in mariculture. Aquaculture. 170: $147-159$ 
Roy S.S. and R. Pal . 2015. Microalgae in Aquaculture: A Review with Special References to Nutritional Value and Fish Dietetics. Proceedings of the Zoological Society 68 (1): 1-8 (doi:10.1007/ s12595-013-0089-9)

Schenk, P. M., S. R. Thomas-Hall, E. Stephens, U. C. Marx, J. H. Mussgnug, C. Posten, O. Kruse, and B. Hankamer, 2008. Second generation biofuels : High-efficiency microalgae for biodiesel production. Bioenerg. Res., 1: 20-43.

Skjanes, K. C. Rebours, and P. Lindblad 2012. Potential for green microalgae to produce hydrogen, pharmaceuticals and other high value products in a combined process. Critical Reviews in Biotechnology 33 (2). (http://dx.doi.or $\mathrm{g} / 10.3109 / 07388551.2012 .68$ 1625)
Spolaore, P., C. Joannis-Cassan, E. Duran and A. Isambert 2006. Commercial applications of microalgae. Journal of Bioscience and Bioengineering. 101(2) : 87-97 (http://dx. doi.org/10.1263/jbb.101.87)

Stengel, D.B., S. Conan and Z.A. Popper 2011. Algal chemodiversity and bioactivity: sources of natural variability and implications for commercial application. Biotechnol Adv 29 (5):483-501. (doi:10.1016/j. biotechadv.2011.05.016)

Supriya, G and T.V. Ramachandra. 2011. Chronicle of Marine Diatom Culturing Techniques. Indian Journal of Fundamental and Applied Life Sciencesl(3) : 282-294 